\title{
DIEL VERTICAL MIGRATION OF COPEPODS IN A BRAZILIAN LAKE: A MECHANISM FOR DECREASING RISK OF Chaoborus PREDATION?
}

\author{
PERTICARRARI, A., ARCIFA, M. S. and RODRIGUES, R. A. \\ Departamento de Biologia, FFCLRP, Universidade de São Paulo, Av. Bandeirantes, 3900, \\ CEP 14040-901, Ribeirão Preto, SP, Brazil \\ Correspondence to: Marlene Sofia Arcifa, Departamento de Biologia, FFCLRP, Universidade de São Paulo, \\ Av. Bandeirantes, 3900, CEP 14040-901, Ribeirão Preto, SP, Brazil, e-mail: marcifa@usp.br \\ Received August 24, 2002 - Accepted February 24, 2003 - Distributed May 31, 2004
}

(With 8 figures)

\begin{abstract}
A comparison between two studies on diel vertical migration of two cyclopoid copepod species, in Lake Monte Alegre, undertaken in 1985/86 and 1999, revealed a change in their migratory behavior. In summer, during a period of marked stratification with low dissolved oxygen near the bottom, the organisms avoided the deepest layers, and migration was nocturnal or undetectable, in both periods. On other occasions, with partial or total circulation in the lake, a weak twilight migration of copepodites and adults in 1985 was replaced by the reverse in 1999. Differences were found among stages, with the weakest or undetectable migration being observed for nauplii. The migratory pattern change for copepodites and adults might be related with a recent predation pressure increase by Chaoborus larvae on copepods, after the virtual disappearance of their main cladoceran prey.
\end{abstract}

Key words: reverse migration, cyclopoid copepods, Chaoborus predation.

\section{RESUMO}

\section{A migração vertical de copépodos em um lago brasileiro: um mecanismo para diminuir o risco de predação por Chaoborus?}

A comparação entre dois estudos sobre migração vertical diária de duas espécies de copépodos ciclopóides no Lago Monte Alegre, realizados entre 1985/86 e 1999, revelou mudança em seu comportamento migratório. No verão, durante período de marcada estratificação, com pouco oxigênio dissolvido próximo ao fundo, as camadas mais profundas foram evitadas pelos organismos e a migração foi noturna ou não ocorreu. Em outras ocasiões, com circulação parcial ou total do lago, uma fraca migração crepuscular de copepoditos e adultos, em 1985, foi substituída por reversa em 1999. Foram encontradas diferenças entre os estágios, sendo que os náuplios não migraram ou migraram fracamente. A mudança do padrão migratório de copepoditos e adultos poderia estar relacionada a recente aumento da predação de copépodos por larvas de Chaoborus, depois do desaparecimento virtual do cladócero, sua presa principal.

Palavras-chave: migração reversa, copépodo ciclopóide, predação por Chaoborus.

\section{INTRODUCTION}

Despite extensive research on diel vertical migration (reviews by Cushing, 1951; Bainbridge,
1961; Hutchinson, 1967; Longhurst, 1976; Kerfoot, 1985; Bayly, 1986; Haney, 1988; Ringelberg, 1993), questions still remain about its ultimate causes. If light is considered the most important factor for 
triggering and controlling the process (Buchanan \& Haney, 1980; Ringelberg, 1980, 1991), there is no agreement concerning the adaptive value.

Decrease of predation risk by visual and nonvisual predators as a result of prey vertical migration, gained greater importance as an ultimate cause from the seventies on (Zaret \& Suffern, 1976; Wright et al., 1980; Stich \& Lampert, 1981; Ohman et al., 1983; Lampert \& Taylor, 1985; Gliwicz, 1986; Ohman, 1990). Nocturnal migration has been reported as the common zooplankton behavior while reverse migration is regarded as an unusual pattern (Bayly, 1986). Reverse migration by smaller zooplanktonic organisms might lower predation by larger planktonic invertebrates which, on the other hand, migrate nocturnally to escape from visual vertebrate predators (Lampert, 1993).

In Lake Monte Alegre, known predators of planktonic microcrustaceans are Chaoborus larvae (Arcifa, 2000; Castilho-Noll, 2002), a water mite (Cassano et al., 2002), and adult Tilapia rendalli (Arcifa \& Meschiatti, 1996). Water mites prey on cladocerans but not on copepods, and tilapias are mainly phytoplanktivores, catching mostly cladocerans in the water current produced by their pumping filterfeeding. Chaoborus larvae II-IV are the main copepod predators.

Two studies done 13 years apart on diel vertical migration of microcrustaceans in Lake Monte Alegre allowed a comparison of patterns under different predation pressure degrees by Chaoborus larvae. The virtual disappearance of their favorite cladoceran prey (Arcifa, 2000) resulted in an increase of larvae predation on copepods (Castilho-Noll, 2002).

The purpose of this paper is to compare the diel vertical migration behavior in Lake Monte Alegre, in 1985/86 and 1999, of copepods subject to lower and higher predation pressure by Chaoborus larvae. The effect, in both periods, of low oxygen concentrations as a counteracting stimulus influencing vertical migration pattern is also discussed.

\section{STUDY AREA}

Lake Monte Alegre $\left(21^{\circ} 11^{\prime} \mathrm{S}, 47^{\circ} 43^{\prime} \mathrm{W}\right)$ is a small, shallow, eutrophic reservoir (area $7 \mathrm{ha}, \mathrm{Z}_{\max }=$ 5 m). Located in Ribeirão Preto, São Paulo State, at a $500 \mathrm{~m}$ altitude, it resulted from damming the Laureano Creek, of the Pardo River Basin in 1942. As the outlet is superficial, the dam is not manipulated by man, and the retention time (ca. 45 days) is relatively high for the lake dimensions it functions as a lake. It may stratify for relatively long periods in the warm season, resulting in low concentrations of, or depleted oxygen near the bottom. Surface temperatures range from 19 to $30^{\circ} \mathrm{C}$, conductivity from 47 to $96 \mu \mathrm{S} . \mathrm{cm}^{-1}$, and $\mathrm{pH}$ from 5.5 to 8.0. The lake is located in a tropical climate region with a marked dry-cool season (May-September) and wet-warm season (October-April). General abiotic and biotic features of the lake can be found in Arcifa (1999).

\section{MATERIAL AND METHODS}

Samples were taken, from each meter of the water column, with a small electric pump delivering $30 \mathrm{~L} . \mathrm{min}^{-1}$; the water was filtered in a $60 \mu \mathrm{m}$ net. Zooplankton was narcotized and preserved in formaldehyde 4\%, according to Haney \& Hall (1973).

Two 24 h-samplings were made in 1985/1986, in July 1985 and in February/March 1986, and four in 1999, in February, March, April, and November. At the same time, physical and chemical measurements were taken: temperature and dissolved oxygen with a thermometer coupled to a Ruttner bottle and Winkler's method, respectively, in 1985/ 86, and with a YSI 95 in 1999; light intensity with a photometer LI 250 in 1999. At noon and midnight in 1999, water samples were taken at each meter, filtered through Sartorius glass fiber filters, and the chlorophyll-a was analyzed by Lorenzen's method (1967).

Juvenile and adult copepods were counted in 1, 2.5, or $5 \mathrm{ml}$ subsamples, taken with Stempel pipettes, attaining at least a minimum of 60 individuals in each one; several subsamples were counted in order to maintain a coefficient of variation lower than 0.20 , according to recommendations of McCauley (1984) and Prepas (1984). Chaoborus larvae and low density samples were fully counted.

For November 1999, the vertical distribution of copepods was represented by quartile curve diagrams (Pennak, 1943) and also by a isopleth diagram.

Spatial overlap between adult copepods and Chaoborus instar IV was obtained by first transforming all density values into percentages, and then evaluating the percentage overlap for each depth. Graphic representation was made by summing the overlap percentages in the water column, on each time a within $24 \mathrm{~h}$-sampling. 


\section{RESULTS}

\section{Physical and chemical factors}

Surface temperatures ranged from $27^{\circ}$ to $30^{\circ} \mathrm{C}$ in the warm season, and $19^{\circ}$ to $25^{\circ} \mathrm{C}$ in the cool season in both periods (1985/86 and 1999).

Also, in both periods lake stratification was established in summer, with a thermocline located between 2 and 3 to $3.5 \mathrm{~m}$, having a gradient of ca. $1.5^{\circ} \mathrm{C}$. In February 1986 and 1999 as a consequence of thermal stratification, dissolved oxygen (DO) was unevenly distributed in the water column (Figs. 1A, 2A). Below 4 m, DO dropped to near-zero in 1999, or was depleted in 1986. During the cool season in the winter of 1985 (July) and the autumn of 1999 (April), DO concentrations were relatively high in the water column, indicating a period of partial or total circulation (Figs. 1B, 2B). In March 1999, oxygen distribution was similar to that in February, but with higher values near the bottom; in November, it was like that in April.

Light was quickly attenuated in the water column in all sampling periods in 1999, as shown by light intensity profiles of February and April (Fig. 2C, D).

\section{Chlorophyll-a distribution}

In February and April 1999 (Fig. 3A, B), as well as in March and November, by day, chlorophyll concentrations were higher in the upper layers, and increased in deeper ones at night.

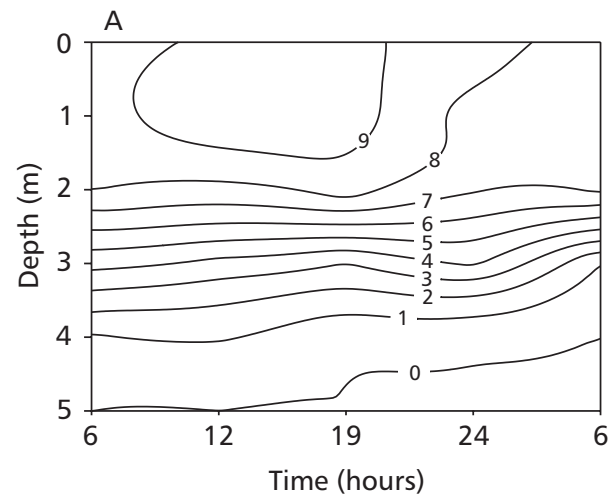

\section{Vertical distribution of copepods in 1985/1986 and} 1999

In both February/March 1986 and February 1999 (Figs. 4A, 5A), most juveniles and adults avoided the deepest layers, where oxygen concentrations were very low or depleted in summer.

In the summer of 1986, some of the adults of Tropocyclops prasinus ascended to upper layers after sunset, in a weak nocturnal migration (Fig. 4A). In the winter of 1985, nauplii, copepodites, and adults of $T$. prasinus showed a weak twilight vertical pattern (Fig. 4B).

In 1999, migration was undetectable for nauplii except in February when a nocturnal pattern was observed (Fig. 5). After a slight trend towards nocturnal or undetectable migration in February (Fig. 5A), copepodites and adults of both species reverse migrated in March and April (Fig. 5B, C). For November, the pattern for $T$. prasinus copepodites and adults is not clearly shown by quartile curves (Fig. 5D), although they seemed to remain in the same layer day and night, with only part of them ascending at sunset. The isopleth diagram was more effective in showing that most copepodites remained in deeper layers on a diel cycle, while most adults were distributed in upper layers at daytime, occupying the deepest one after sunset (Fig. 6). Therefore, in general, copepodites and adults showed a strong tendency for reverse migrating.

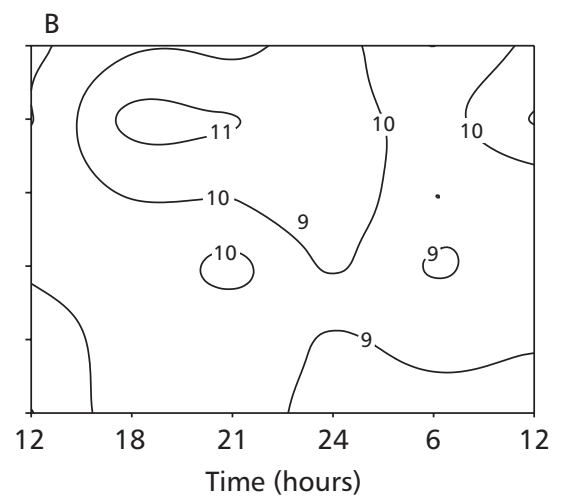

Fig. 1 - Dissolved oxygen isopleths, at intervals of $1 \mathrm{mg} . \mathrm{L}^{-1}$, in $24 \mathrm{~h}$ periods, in the summer of 1986 (A) and the winter of 1985 (B). 

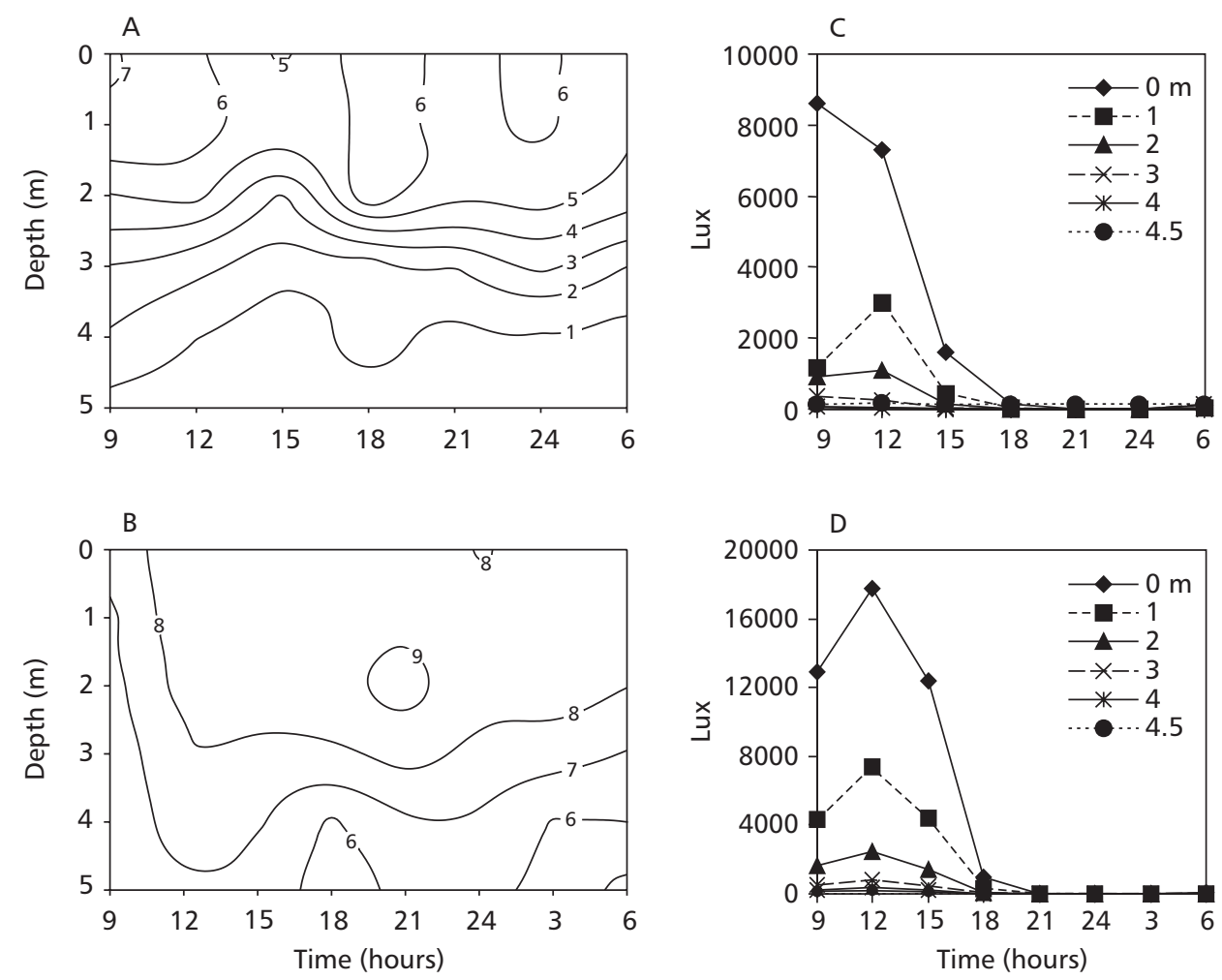

Fig. 2 - Dissolved oxygen isopleths, at intervals of $1 \mathrm{mg} \cdot \mathrm{L}^{-1}$, in $24 \mathrm{~h}$ periods, in February (A) and April (B), and light intensity in the water column in February (C) and April (D) of 1999.

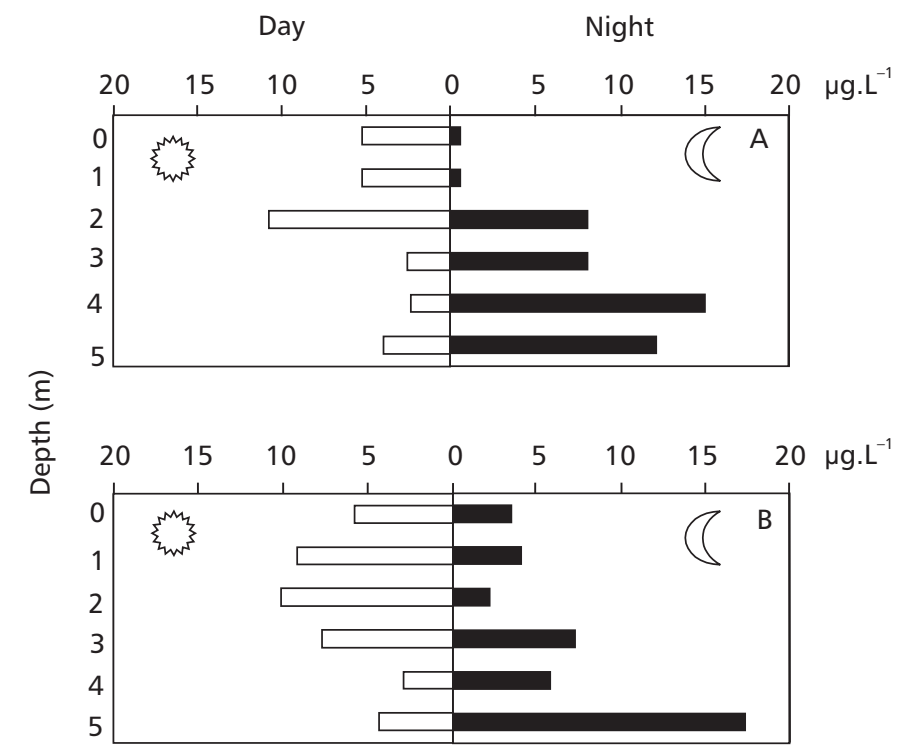

Fig. 3 - Vertical distribution of chlorophyll- $a$, in $\mu \mathrm{g} . \mathrm{L}^{-1}$, in February (A) and April (B) of 1999. 

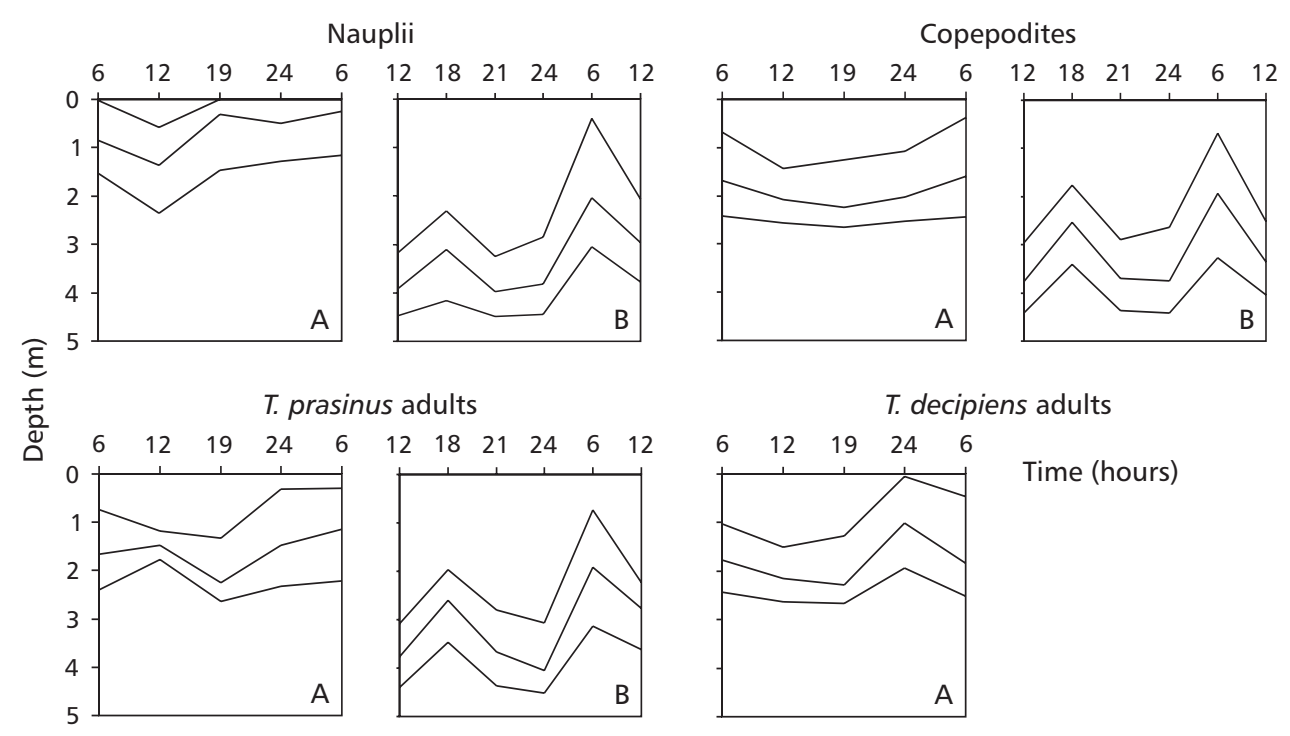

Fig. 4 - Vertical distribution of copepod stages represented by quartile curves, in February-March of 1986 (A) and July of 1985 (B).

In the summer of 1986, the clearly established nocturnal migration of Chaoborus instar IV led to a very low spatial overlap with $T$. prasinus, during the day (Fig. 7A). When adult copepods migrated in a weak nocturnal way, as in February 1999, the spatial overlap with Chaoborus instar IV was, generally, higher than when they (in the other months) on a diel cycle (Fig. 7B, C). This holds specially for Tropocyclops prasinus (Fig. 7B).

\section{DISCUSSION}

In Lake Monte Alegre in the summers of 1985/ 86 and 1999, copepods occupied mostly the upper layers, occurring in lower numbers in the deepest ones. This was the result of a counteracting stimulus (Ringelberg, 1980) represented by low dissolved oxygen concentrations beneath $3.5 \mathrm{~m}$. Avoidance of poorly oxygenated layers by migratory crustaceans is common and has been reported for other Brazilian water bodies (Okano, 1980; Fisher et al., 1983; Matsumura-Tundisi et al., 1984).

Comparing copepod diel migration in both $1985 / 86$ and 1999, there was a clear trend towards reverse migration in the latter, except during a stronger thermal and oxygen stratification period (February). This raises the question of what has changed in the lake from the first to the second period and whether the new copepod migration pattern is related to any adaptive value.

In both periods but in different proportions, Chaoborus larvae always included copepods in their diets. Copepods contributed ca. $4 \%$ to the diet of instars III and IV in 1985/86, and $13 \%$ and $18 \%$, respectively, in 1999 (Fig. 8). The cladoceran Bosmina tubicen, which was the favorite prey in the eighties (Arcifa, 2000), virtually disappeared from the lake in 1999 (Fileto, 2001). In 1985/86, lower densities of the cladoceran prey $B$. tubicen and Daphnia gessneri, at some times in the lake, ended in a higher consumption of alternative items (Arcifa, op. cit.). When this happened, the usual contribution of copepods to the diets of larvae III and IV (2.5 to $5 \%$ ) increased to, $14 \%$ or $15 \%$, respectively. Therefore, copepods occasionally faced a higher predation pressure in 1985/86, which was the rule in 1999.

Chaoborus larvae II-IV migrated nocturnally in $1985 / 86$, the last instar disappearing from the water column at noon (Arcifa, 1997). Migratory behavior of the larvae was not so clearly defined in 1999 as it had been in the previous period (Perticarrari, 2000). Three kinds of behavior were observed in 1999: larvae were either distributed in the water column, or migrated nocturnally, or even showed a slight trend to reverse migration. Instars III and IV, however, were 
found during the day in the sediment in higher densities which decreased at night (S. E. N. Cleto Filho, in preparation). So, at least a part of the oldest larvae descends to the sediment during the day, ascending to the water column at night. Chaoborus larvae can be preyed on by fish (Arcifa \& Meschiatti, 1993) and the water mite Krendowskia sp. (Cassano et al., 2002). In 1999, mites were present in the lake and usually migrated nocturnally (Perticarrari, 2000), but were virtually absent in 1985/86. Larvae migratory behavior in 1999 could be related to the presence of a new predator.

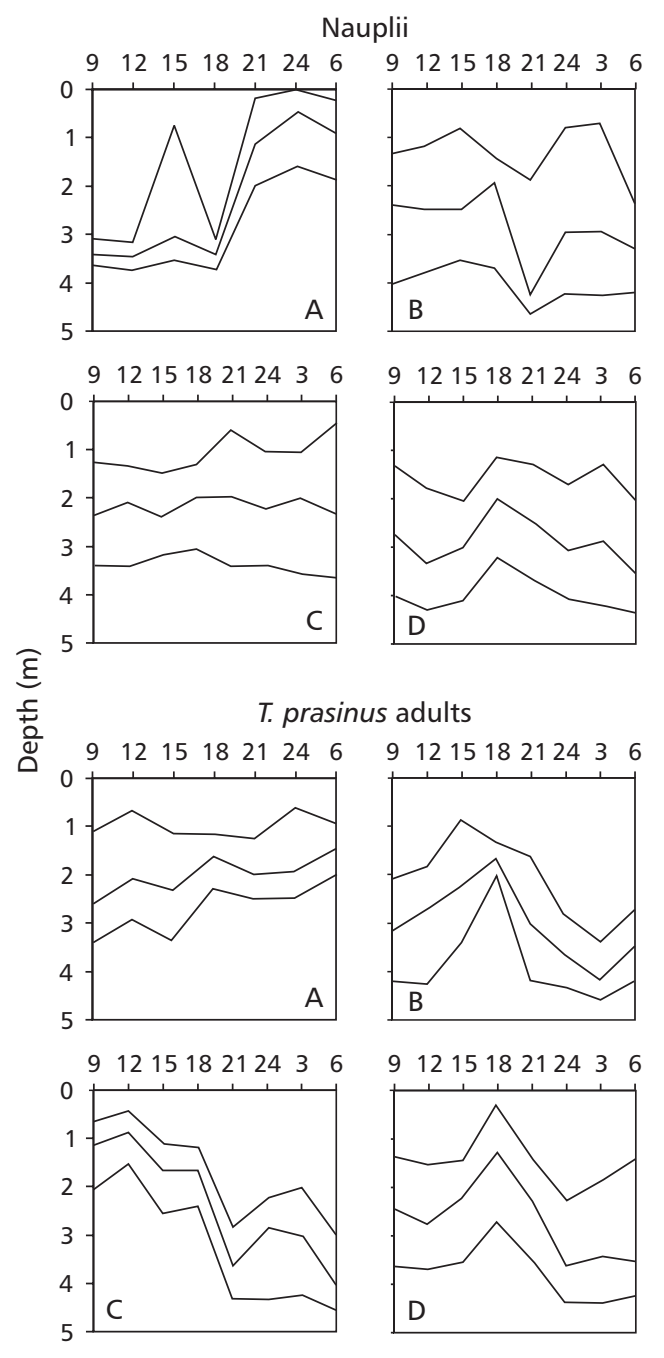

It is possible that the reverse diel migration adopted by both copepod species in Lake Monte Alegre in 1999 was a response to an increase in predation pressure by Chaoborus larvae after the virtual disappearance of their previous favorite prey, Bosmina tubicen. Although both prey and predator still in the water column, when prey encountered reverse migrated there was a lower spatial overlap at some hours compared to that existing when it migrated nocturnally (February). The lower spatial overlap with Chaoborus, on a diel cycle, is possibly advantageous for prey.

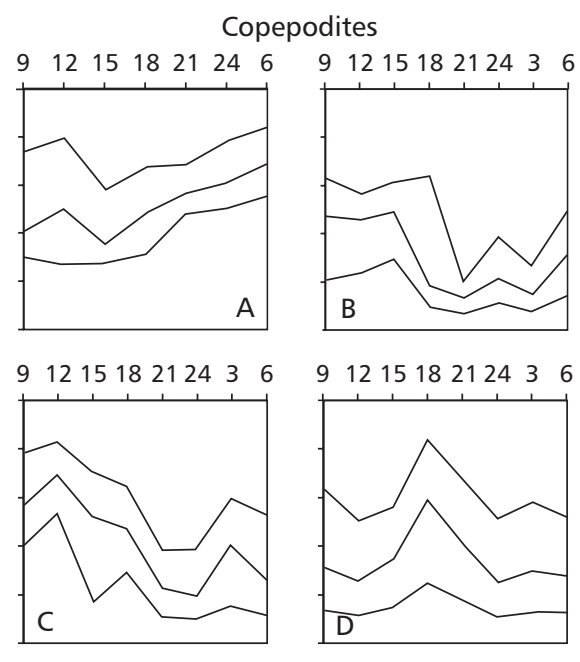

T. decipiens adults
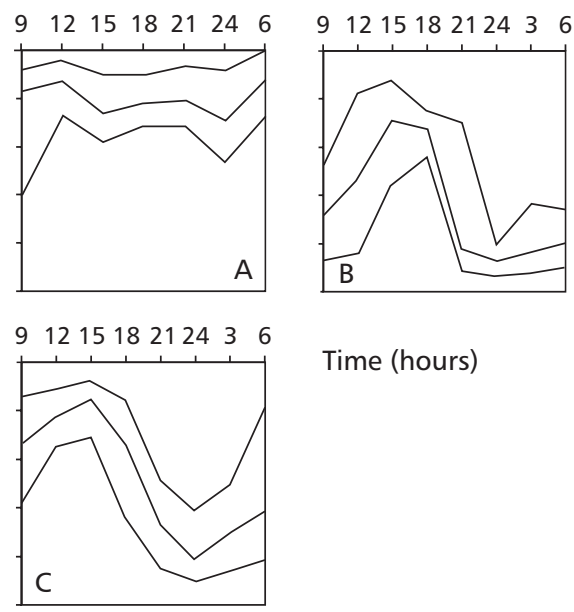

Fig. 5 - Vertical distribution of copepod stages represented by quartile curves, in February (A), March (B), April (C), and November (D) of 1999. 

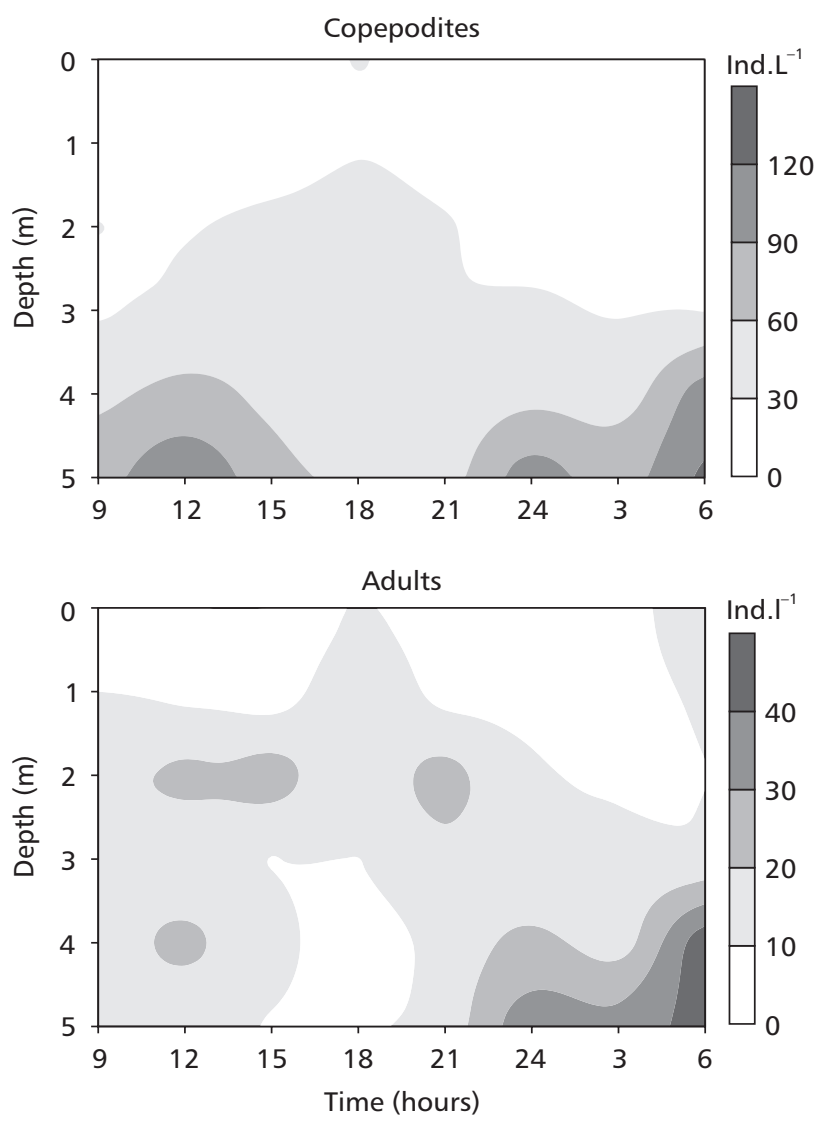

Fig. 6 - Vertical distribution of Tropocyclops prasinus represented by isopleths, in November of 1999.

In a mesocosm experiment run from 9/II to 8/ III/1999 on Chaoborus predation on zooplankton, copepods were less affected by predators than were cladocerans (Castilho-Noll, 2002). Mortality rates of Daphnia gessneri, which migrated nocturnally in the lake (Perticarrari, 2000), were significantly higher than those of copepods in enclosures with predators. As the experimental period and the first two $24 \mathrm{~h}$ samplings (February, March) mostly coincided, it is plausible to suppose that microcrustaceans behaved in the same way in the lake and in the enclosures with Chaoborus. Thus, while oxygen concentrations were lower near the bottom at the start of the experiment, copepodites and adults possibly migrated within the upper layers or remained there day and night (as in Fig. 5A). However, from the middle to the end of the experimental period, when oxygen was above 1 mg. $\mathrm{L}^{-1}$, they possibly reverse migrated.

Reverse diel migration can be advantageous for zooplankton by reducing predation risk by invertebrate predators, which migrate nocturnally to escape from visual vertebrate predators.

A marine copepod, Pseudocalanus sp., exhibited an unusual reverse diel migration, whereas their invertebrate predators migrated nocturnally (Ohman et al., 1983). A small reduction of mortality rate of adult female copepods, due to decrease of spatial overlap with predators, was advantageous for migratory individuals. Later (Ohman, 1990), Pseudocalanus newmani was reported exhibiting three migratory behaviors: nocturnal where diurnal predation by planktivorous fish was most important; reverse, under higher predation pressure by invertebrates migrating in a nocturnal way; and non-migrating, when predation was low in surface waters. Ohman also found that copepodites I to III, which suffered a lower predation pressure by invertebrates, did not exhibit a detectable migration. In 1999, in Lake Monte Alegre, nauplii, which is a minor Chaoborus prey 
(Fig. 8), also showed an undetectable pattern on three sampling occasions, and nocturnal migration on one (February).

Enclosure experiments with addition of Chaoborus larvae resulted in reverse migration of the copepod Diaptomus kenai, a quick response $(<4$ h) of previously non-migrating individuals (Neill, 1990). Copepods used to reverse migrate when Chaoborus was present in the lake, stopped migrating after predator elimination by trout, introduced 28 months before the enclosure experiments. In addition, Fedorenko (1975a, b) found that $D$. kenai reverse migrated and states that a lower spatial overlap between Chaoborus and copepod may result in lower predation.

Daphnids shifted from nocturnal to reverse migration after the removal of surface-orienting insects from manipulated ponds (Herwig \& Schindler, 1996). The authors considered the new behavior as a way to reduce overlap with Chaoborus IV, which became the main predator and continued to migrate nocturnally.

Food distribution is another aspect to be taken into account in Lake Monte Alegre. Considering that chlorophyll-a concentrations increased towards the bottom at night in 1999, it would have been advantageous for herbivores to descend for feeding noctunally. Cyclopoid nauplii are obligate herbivores (Pourriot \& Lescher-Moutoué, 1983) while older stages are usually omnivores. Nauplii should reverse migrate to feed on algae where they are most abundant, whether in the upper layers during the day or the deeper ones at night. But, instead, copepodites and adults are the ones that reverse migrate.

Therefore, it is plausible to suppose that the reverse migration pattern of copepods, shown recently in Lake Monte Alegre, is more advantageous for decreasing Chaoborus predation pressure.

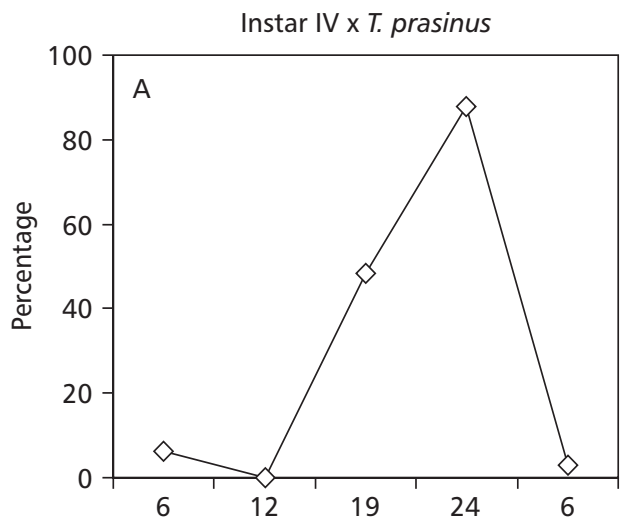

Legend

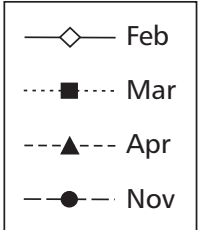

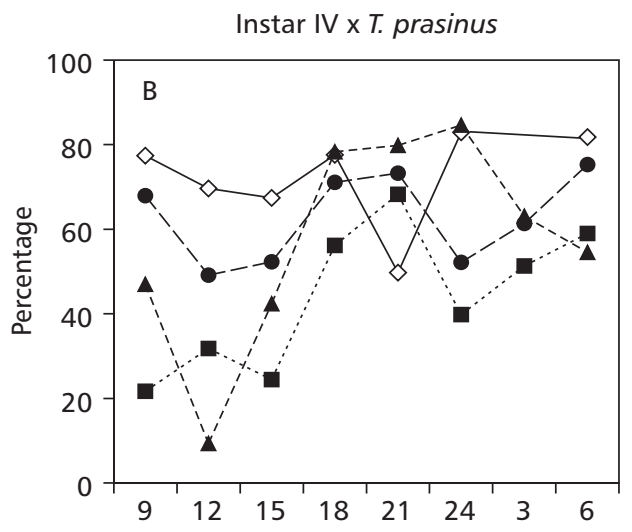

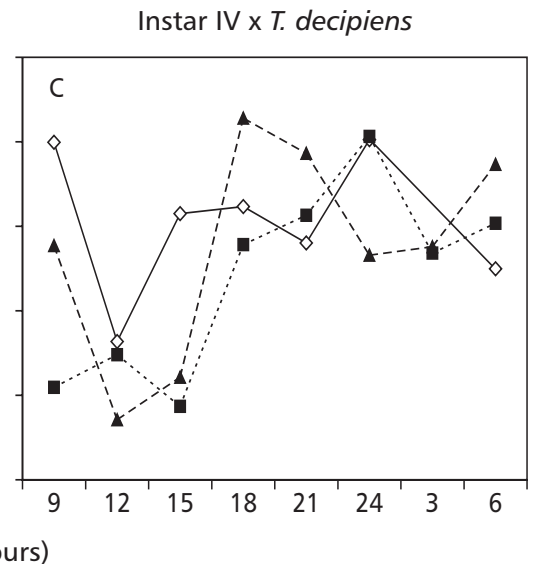

Fig. 7 - Spatial overlap between Chaoborus instar IV and adult copepods, in the summer of 1986 (A), and in 1999 (B, C). 

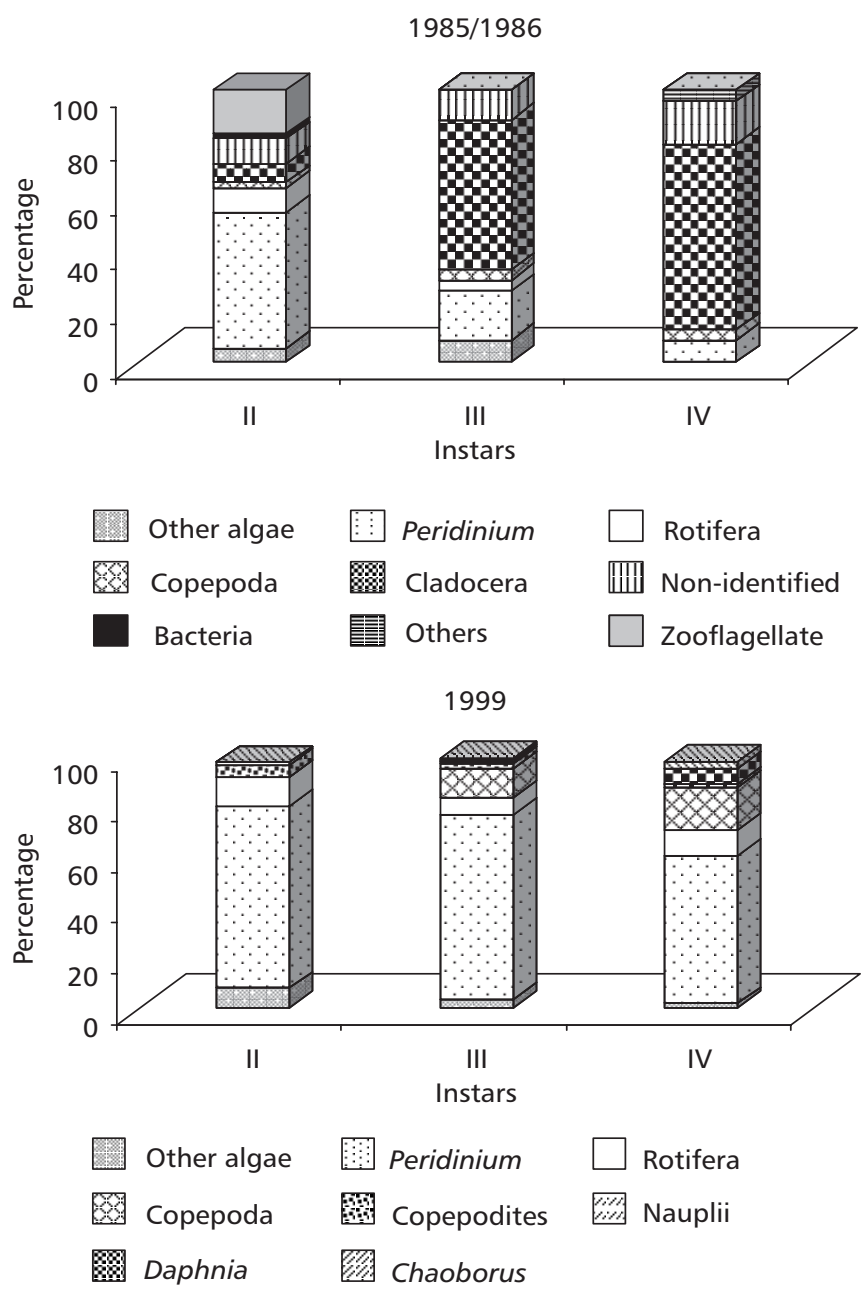

Fig. 8 - Relative volume of items in the diet of Chaoborus larvae II to IV, in 1985/86 and 1999. Sources: Arcifa (2000) and Castilho-Noll (2002).

Acknowledgments - We thank all the laboratory staff and graduate students for help in the field, and Fapesp for financial support to M. S. A. (n. 1997/10407-6) and grants to A. P. (n. 1998/11478-7) and R. A. R. (n. 1985/2157-2). We also thank J. A. Jorge and V. R. Balbo for help with chlorophyll-a readings.

\section{REFERENCES}

ARCIFA, M. S., 1997, Fluctuations and vertical migration of Chaoborus in a tropical Brazilian reservoir: Lake Monte Alegre. Acta Limnol. Brasil., 9: 93-103.

ARCIFA, M. S., 1999, Lago Monte Alegre: uma visão sobre a estrutura e hipóteses de funcionamento. In: R. Henry (ed.), Ecologia de Reservatórios: estrutura, função e aspectos sociais. Fundibio: Fapesp, Botucatu, pp. 55-76.

ARCIFA, M. S., 2000, Feeding habitats of Chaoborus in a tropical Brazilian reservoir. Rev. Brasil. Biol., 60: 591-597.
ARCIFA, M. S. \& MESCHIATTI, A. J., 1993, Distribution and feeding ecology of fishes in a Brazilian reservoir: Lake Monte Alegre. Interciencia, 18: 302-313.

ARCIFA, M. S. \& MESCHIATTI, A. J., 1996, Tilapia rendalli in the Lake Monte Alegre, a case of planktivory. Acta Limnol. Brasil., 8: 221-229.

BAINBRIDGE, R., 1961, Migrations. In: T. H. Waterman (ed.), The Physiology of Crustacea 2. Academic Press, New York, pp. 431-463.

BAYLY, I. A. E., 1986, Aspects of diel vertical migration in zooplankton and its enigma variations. In: P. De Deckker \& W. D. Williams (eds.), Limnology in Australia. Csiro \& Dr. W. Junk Publ., Melbourne, pp. 349-368.

BUCHANAN, C. \& HANEY, J. F., 1980, Vertical migration of zooplankton in the Arctic: a test of the environmental control. In: W. C. Kerfoot (ed.), Evolution and Ecology of Zooplankton Communities. Univ. Press New England, Hanover, pp. 69-79. 
CASTILHO-NOLL, M. S. M., 2002, A predação de larvas de Chaoborus brasiliensis sobre populações zooplanctônicas. Tese de Doutorado, IB/USP, São Paulo, 101p.

CASSANO, C. R., CASTILHO-NOLL, M. S. M. \& ARCIFA, M. S., 2002, Water mite predation on zooplankton of a tropical lake. Braz. J. Biol., 62(4A): 565-571.

CUSHING, D. H., 1951, The vertical migration of planktonic Crustacea. Biol. Rev. Cambridge Phil. Soc., 26: 158-192.

FEDORENKO, A. Y., 1975a, Instar and species-specific diets in two species of Chaoborus. Limnol. Oceanogr., 20(2): 238249.

FEDORENKO, A. Y., 1975b, Feeding characteristics and predation impact of Chaoborus (Diptera, Chaoboridae) larvae in a small lake. Limnol. Oceanogr., 20(2): 250-258.

FILETO, C., 2001, O zooplâncton do Lago Monte Alegre: variação temporal e a influência das frações do fitoplâncton sobre o crescimento e reprodução de cladóceros. Dissertação de Mestrado, FFCLRP/USP, Ribeirão Preto, 100p.

FISHER, T. R., MELACK, J. M., ROBERTSON, B., HARDY, E. R. \& ALVES, L. F., 1983, Vertical distribution of zooplankton and physico-chemical conditions during a 24-hour period in an Amazon floodplain lake - lago Calado, Brazil. Acta Amazonica, 13(3-4): 475-487.

GLIWICZ, M. Z., 1986, Predation and the evolution of vertical migration in zooplankton. Nature, 320: 746-748.

HANEY, J. F., 1988, Diel patterns of zooplankton behaviour. Bull. Mar. Sci., 43: 583-603.

HANEY, J. F. \& HALL, D. J., 1973, Sugar-coated Daphnia: A preservation technique for Cladocera. Limnol. Oceanogr., 18: 331-333.

HERWIG, B. R. \& SCHINDLER, D. E., 1996, Effects of aquatic insect predators on zooplankton in fishless ponds. Hydrobiologia, 324: 141-147.

HUTCHINSON, G. E., 1967, A Treatise on Limnology. II. Introduction to Lake Biology and the Limnoplankton. John Wiley \& Sons, New York, 1115p.

KERFOOT, W. C., 1985, Adaptive value of vertical migration: comments on the predation hypothesis and some alternatives. Contrib. Mar. Sci., sup. 27: 91-113.

LAMPERT, W. \& TAYLOR, B. E., 1985, Zooplankton grazing in a eutrophic lake: implications of diel vertical migration. Ecology, 66: 68-82.

LAMPERT, W., 1993, Ultimate causes of diel vertical migration of zooplankton: New evidence for the predator-avoidance hypothesis. Arch. Hydrobiol. Beih. Ergebn. Limnol. Stuttgart, 39: 79-88

LONGHURST, A. R., 1976, Vertical migration. In: D. H. Cushing \& J. J. Walsh (eds.), The Ecology of the Seas. Blackwell Sci. Publ, London, pp. 116-137.

LORENZEN, C. J., 1967, Determination of chlorophyll and pheopigments: spectro-photometric equations. Limnol. Oceanogr., 12: 343-346.

MATSUMURA-TUNDISI, T., TUNDISI, J. G. \& TAVARES, L. S., 1984, Diel migration and vertical distribution of Cladocera in Lake D. Helvecio (Minas Gerais, Brazil). Hydrobiologia, 113: 299-306.
MCCAULEY, E., 1984, The estimation of the abundance and biomass of zooplankton in samples. In: J. A. Downing \& J. A. Rigler (eds.), A Manual on Methods for the Assessment of Secondary Productivity in Fresh Waters. Blackwell Sci. Publ, London, pp. 228-265.

NEILL, W. E., 1990, Induced vertical migration in copepods as a defence against invertebrate predation. Nature, 345 : 524-526.

OHMAN, M. D., 1990, The demographic benefits of diel vertical migration by zooplankton. Ecol. Monogr., 60: 257-281.

OHMAN, M. D., FROST, B. W. \& COHEN, E. B., 1983, Reverse diel vertical migration: an escape from invertebrate predators. Science, 220: 1404-1406.

OKANO, W. Y., 1980, Padrão de migração vertical e flutuação sazonal das principais espécies de Copepoda (Crustacea) do lago Dom Helvécio. Parque florestal do Rio Doce, MG. Lago Dom Helvécio, Minas Gerais, Brasil. Dissertação de Mestrado, UFSCar, São Carlos, 168p.

PENNAK, W. R., 1943, An effective method of diagramming diurnal movements of zooplankton organisms. Ecology, 24: 405-407.

PERTICARRARI, A., 2000, Migração vertical de microcrustáceos, Chaoboridae e Hydracarina no Lago Monte Alegre. Dissertação de Mestrado, FFCLRP/USP, Ribeirão Preto, 94p.

POURRIOT, R. \& LESCHER-MOUTOUÉ, F., 1983, Problèmes de stratégies alimentaires chez le zooplâncton d' eau continentale. Bull. Soc. Zool. France, 108: 485-498.

PREPAS, E. E., 1984, Some statistical methods for the design of experimental and analysis of samples. In: J. A. Downing \& J. A. Rigler (eds.), A Manual on Methods for the Assessment of Secondary Productivity in Fresh Waters. Blackwell Sci. Publ, London, pp. 266-335.

RINGELBERG, J., 1980, Introductory remarks: Causal and teleological aspects of diurnal vertical migration. In: W. C. Kerfoot (ed.), Evolution and Ecology of Zooplankton Communities. Univ. Press New England, Hanover, pp. 6568.

RINGELBERG, J., 1991, The relation between ultimate and proximate aspects of diel vertical migration in Daphnia hyalina. Verh. Internat. Verein. Limnol., 24: 2804-2807.

RINGELBERG, J. (ed.), 1993, Diel vertical migration of zooplankton. Arch. Hydrobiol. Beih. Ergebn. Limnol. Stuttgart, 222p.

STICH, H. B. \& LAMPERT, W., 1981, Predation evasion as an explanation of diurnal vertical migration by zooplankton. Nature, 293: 396-398.

WRIGHT, D., O'BRIEN, W. J. \& VINYARD, G. L., 1980, Adaptive value of vertical migration: a simulation model argument for the predation hypothesis. In: W. C. Kerfoot (ed.), Evolution and Ecology of Zooplankton Communities. Univ. Press of New England, Hanover, pp. 138-147.

ZARET, T. M. \& SUFFERN, J. S., 1976, Vertical migration in zooplankton as a predator avoidance mechanism. Limnol. Oceanogr., 21: 804-813. 